\title{
Risk factors for neonatal hyperbilirubinemia: a case control study
}

\section{Sumangala Devi, Bindu Vijaykumar*}

Department of Obstetrics and Gynecology, Government Medical College, Kozhikode, Kerala, India

Received: 27 October 2016

Revised: 02 December 2016

Accepted: 29 December 2016

\section{*Correspondence:}

Dr. Bindu Vijaykumar,

E-mail: bindu.vk@gmail.com

Copyright: (C) the author(s), publisher and licensee Medip Academy. This is an open-access article distributed under the terms of the Creative Commons Attribution Non-Commercial License, which permits unrestricted non-commercial use, distribution, and reproduction in any medium, provided the original work is properly cited.

\begin{abstract}
Background: Neonatal Hyperbilirubinemia is one of the most common reasons for NICU admissions. The frequency of neonatal jaundice has been on an increase since the last decade. Is the increase due to changes in obstetric practice or drugs? There is no definite reason. This study was undertaken to find out any obstetric characteristics which may contribute to the development of Neonatal Hyperbilirubinemia and which is modifiable.

Methods: Record review data from 140 singleton deliveries at the Institute of Maternal \& Child Health ,Govt. Medical College, Kozhikode, Kerala were analyzed to determine the relationship between neonatal hyperbilirubinemia $(>10 \mathrm{mg} / \mathrm{dl})$ and maternal characteristics. Confounding variables were controlled by multiple logistic regression analysis.

Results: There was statistically significant relationship between hyperbilirubinemia and LBW, preterm delivery, PPROM, breast feeding, neonatal infection, instrumental delivery and presence of GDM and IUGR.

Conclusions: By identifying these obstetric characteristics, we may be able to modify them and reduce the need for NICU admissions for Neonatal Hyperbilirubinemia.
\end{abstract}

Keywords: Bilirubin, Low Birth weight, Hyperbilirubinemia, Kernicterus, Prematurity

\section{INTRODUCTION}

Neonatal hyperbilirubinemia is the most common morbidity in neonatal period. $65 \%$ of term new born develop clinical jaundice in $1^{\text {st }}$ week $(80 \%$ in preterm infants). ${ }^{1}$ Neonatal hyperbilirubinemia is defined as TSB $>95^{\text {th }}$ centile for age in hours in term and near term newborns which require follow-up and treatment.

The frequency of significant jaundice of the new born at this hospital has increased from $10 \%$ of all live births in 2000 to $22 \%$ of live births in 2015 . Though mild jaundice of the new born is accepted as normal, severe jaundice is a serious potential cause of permanent brain damage. A sharp increase in the frequency of significant jaundice of the new-born occurred when there were also major changes in obstetric and paediatric practice including an increased use of oxytocics and epidural anaesthesia.
Though the number of live births each year changed little, the number of infants with peak TSB >206 $\mu$ mol $(12 \mathrm{mg} / 100 \mathrm{ml})$ more than doubled as did the numbers with concentrations over $290 \mu \mathrm{mol} / 1$ (>17mg/100ml). In the report, we call a peak TSB $>10 \mathrm{mg} \%$ as significant jaundice depending upon the hours after delivery.

As shown in Figure 1, the guidelines refer to the use of intensive phototherapy which should be used when the TSB exceeds the line indicated for the category.

Although $\mathrm{NNH}$ is a common event, it is of interest because of its extreme consequences and it also can be a source of considerable potential concern. Clinicians need to be aware of the multiple independent risk factors for hyperbilirubinemia and should follow closely neonates with more than 1 risk factor. ${ }^{2}$ 


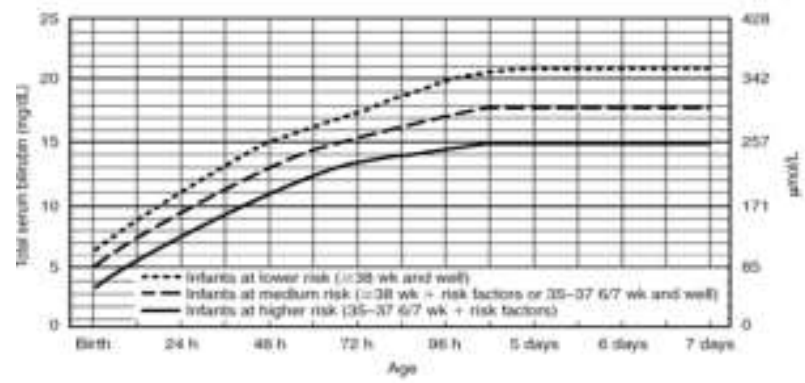

Figure 1: Guidelines for phototherapy in hospitalized infants of 35 or more weeks' gestation.

\section{Aim}

This study was conducted to estimate the incidence of neonatal hyperbilirubinemia in our hospital and to determine the underlying possible causes, relationship of late pregnancy outcomes and a variety of exposures, improved knowledge of which would be valuable to help identify strategies for risk reduction.

Infants with Rh isoimmunisation or active neonatal sepsis were excluded since antenatal and postnatal strategies already exist to prevent occurrence of severe $\mathrm{NNH}$ from these causes.

\section{METHODS}

A case control study was Done in department of Obstetrics and Gynecology, Calicut during the period $1^{\text {st }}$ November $2015-31^{\text {st }}$ December 2015 (2 months).

The case notes of all infants born during the study period who developed peak serum bilirubin concentration of over $10 \mathrm{mg} \%$ were reviewed. A careful search of each case, including the results of laboratory investigations was made and whenever a plausible pathological diagnosis was made, the case was excluded from further consideration.

In our hospital, any baby who becomes jaundiced undergoes routine serum bilirubin estimation. This is repeated daily or more often, until there has been a significant drop in level and jaundice is fading.

$\mathrm{NNH}$ is defined as presence of more than 1 bilirubin estimation of $\geq 10 \mathrm{mg} / \mathrm{dl}$. Information obtained from each women included previous medical and obstetric history and habit characteristics. Women were also asked about previous mode of contraception. Information about infant's gestation and delivery and the occurrence of $\mathrm{NNH}$ were obtained by review of medical records.

Investigations carried out routinely in the study period on all infants with unexplained jaundice were as follows:

- Serial serum Bn

- Mother and infant $\mathrm{ABO}$ and $\mathrm{Rh}$ group
- Infants DCT in albumin and saline

- Maternal antibodies and hemolysins

- $\quad \mathrm{Hb}$, reticount, red cell morphology

- $\quad$ Urine C and S

When indicated - we used to do

- $\quad$ Red cell G6PD assay

- Red cell pyruvate Kinase assay

- Blood culture, lumbar puncture and other bacteriologic studies / viral studies

- Serological studies for toxoplasma and syphilis

Reasons for excluding significantly jaundiced babies

Rh isoimmunisation

ABO incompatibility

Significant infection

G6PD deficiency

Hemoglobinopathies

- There were 70 infants whose jaundice could not be explained.

- A control group of 70 infants born during the study period who did not develop significant jaundice was formed for comparison. Each control infant was matched with a jaundiced infant for maternal age and parity selected from hospital birth register as close as possible to the entry for each jaundiced infant.

\section{Analysis techniques}

We compared maternal demography, pregnancy and delivery events and neonatal outcomes for those infants who had Neonatal hyperbilirubinemia with those who didn't have Neonatal hyperbilirubinemia. For each characteristic, the OR (relative odds) of having hyperbilirubinemia and $95 \%$ confidence interval were calculated. The OR is the estimate of relative risk which can be derived from case control studies. We then performed an analysis by logistic regression to examine the OR of having Neonatal hyperbilirubinemia when all suspected confounders were controlled.

\section{RESULTS}

Table 1 demonstrates demographic variables. The mean maternal age was 25.6years. Mean peak bilirubin level reported was $10 \mathrm{mg} \% .68 \%$ of females were pregnant with first child. The demographic characteristics did not differ significantly between cases and controls.

Table 2 demonstrates the association with past obstetric history. In those patients with previous one or more abortions ( $\mathrm{n}=15$ cases) showed a significant association with the presence of neonatal hyperbilirubinemia [p0.063, OR 2.45 CI (0.86-7.23)]. 
Table 1: Demographic variables.

\begin{tabular}{|clll|}
\hline \multirow{4}{*}{ Age } & \multicolumn{2}{c}{$\begin{array}{l}\text { Cases } \\
(\mathbf{n}=70)\end{array}$} & $\begin{array}{l}\text { Controls } \\
(\mathbf{n}=70)\end{array}$ \\
\cline { 2 - 4 } & $20-30$ & 2 & 3 \\
\cline { 2 - 4 } & $>30$ & 61 & 60 \\
\hline \multirow{3}{*}{ Parity } & Primi & 7 & 7 \\
\cline { 2 - 4 } & Multi & 48 & 31 \\
\cline { 2 - 4 } & Gravida & 4 & 39 \\
\hline
\end{tabular}

Similar association was found with oral contraceptive pill use before conception and neonatal hyperbilirubinemia (15 patients). This was not found to be statistically significant though $[\mathrm{p}=0.269$, OR 1.64: CI (0.63-4.32)].

Table 2: Other associations.

\begin{tabular}{|lll|l|}
\hline & $\begin{array}{l}\text { Cases } \\
(\mathrm{n}=70)\end{array}$ & $\begin{array}{l}\text { Controls } \\
(\mathrm{n}=70)\end{array}$ & $\begin{array}{l}\text { Level of } \\
\text { significance }\end{array}$ \\
\hline BOH & 15 & 7 & $\begin{array}{l}\mathrm{P}=0.063 \\
\mathrm{OR}=2.45 \\
(10.86-7.23)\end{array}$ \\
\hline Pill use & 15 & 10 & $\begin{array}{l}\mathrm{P}=0.269 \\
\text { OR }=1.64 \\
(0.63-4.32)\end{array}$ \\
\hline
\end{tabular}

As shown in table 3, there were significantly more infants of a low gestational age in jaundiced group $(21 \%)[\mathrm{p}<$ $0.0001]$ compared to those delivered at term. There were no preterm deliveries in the control group. Similarly patients with PPROM showed a significant association with the occurrence of neonatal jaundice which is due to associated prematurity.

Table 3: Gestational age at delivery.

\begin{tabular}{|llll|}
\hline & $\begin{array}{l}\text { Cases } \\
(\mathrm{n}=70)\end{array}$ & $\begin{array}{l}\text { Controls } \\
(\mathrm{n}=70)\end{array}$ & $\begin{array}{l}\text { Level of } \\
\text { significance }\end{array}$ \\
\hline Preterm & $15(21 \%)$ & 0 & $\begin{array}{l}\mathrm{P}<0.0001 \\
\text { Statistically } \\
\text { significant }\end{array}$ \\
\hline Term & $55(79 \%)$ & $70(100 \%)$ & $\begin{array}{l}\mathrm{P}=0.269 \\
\text { OR }=1.64 \\
(0.63-4.32)\end{array}$ \\
\hline PRROM & $5(7.14 \%)$ & 0 & $\mathrm{P}<0.058$ \\
\hline
\end{tabular}

Table 4 shows the relation between antenatal complications and neonatal jaundice. Presence of GDM showed a highly significant statistical association with neonatal jaundice [OR being 5.6, CI (1.19-26.9)] and also presence of HTN [OR = 1.7: CI (0.68-4.2)] and IUGR $[\mathrm{OR}=1.3$ : CI (1.68-4.2) $]$ showed a significant association with the occurrence of neonatal jaundice.

Table 5 shows the delivery outcomes for cases and controls. Mode of delivery did not show any statistically significant difference between vaginal delivery and caesarean delivery. $74 \%$ of babies delivered vaginally and $25 \%$ caesarean delivered babies developed neonatal jaundice. The study had 1 case of instrumental delivery in jaundiced group.

Table 4: Antenatal complications.

\begin{tabular}{|llll|}
\hline & $\begin{array}{l}\text { Cases } \\
(n=70)\end{array}$ & $\begin{array}{l}\text { Controls } \\
(n=70)\end{array}$ & $\begin{array}{l}\text { Level of } \\
\text { significance }\end{array}$ \\
\hline HTN & $20 \%$ & $12 \%$ & $\begin{array}{l}\text { OR }=1.7 \\
(0.68-4.2)\end{array}$ \\
\hline IUGR & $13 \%$ & $10 \%$ & $\begin{array}{l}\mathrm{P}<0.05 \\
\text { OR }=1.3 \\
(1.68-4.2)\end{array}$ \\
\hline GDM & $14 \%$ & $3 \%$ & $\begin{array}{l}\mathrm{P}<0.05 \\
\text { OR 5.6 } \\
(1.19-26.9)\end{array}$ \\
\hline
\end{tabular}

Table 5: Mode of delivery.

\begin{tabular}{|llll|}
\hline Spontaneous & $\begin{array}{l}\text { Cases } \\
(\mathrm{n}=70)\end{array}$ & $\begin{array}{l}\text { Controls } \\
(\mathrm{n}=70)\end{array}$ & $\begin{array}{l}\text { Level of } \\
\text { significance }\end{array}$ \\
\hline Induced & $23(34 \%)$ & $17(24 \%)$ & $\begin{array}{l}\mathrm{P}=0.262 \\
\text { Not significant } \\
\text { OR }=1.53 \\
(0.68-3.42)\end{array}$ \\
\hline $\begin{array}{l}\text { Oxytocin } \\
\text { use }\end{array}$ & $\begin{array}{l}62 \\
(88.5 \%)\end{array}$ & $\begin{array}{l}(71.4 \%) \\
\mathrm{P}=0.011 \\
\text { significant }\end{array}$ \\
$\begin{array}{l}\text { OR }=3.10 \\
(1.17-8.44)\end{array}$ \\
\hline $\begin{array}{l}\text { Vaginal } \\
\text { delivery }\end{array}$ & $74 \%$ & $66 \%$ & \\
\hline $\begin{array}{l}\text { Instrumental } \\
\text { delivery }\end{array}$ & $1 \%$ & 0 & \\
\hline $\begin{array}{l}\text { Caesarean } \\
\text { delivery }\end{array}$ & $25 \%$ & $34 \%$ & \\
\hline
\end{tabular}

Table 6: Presumed fetal jeopardy.

\begin{tabular}{|llll|}
\hline MSAF & $\begin{array}{l}\text { Cases } \\
(\mathbf{n}=70)\end{array}$ & $\begin{array}{l}\text { Controls } \\
(\mathbf{n}=70)\end{array}$ & $\begin{array}{l}\text { Level of } \\
\text { significance }\end{array}$ \\
\hline $\begin{array}{l}\text { HR } \\
\text { abnormality }\end{array}$ & $6(7 \%)$ & $2(3 \%)$ & \\
\hline Low Apgar & 8 & $2(1 \%)$ & $\begin{array}{l}\mathrm{P}=0.049 \\
\text { OR }=4.39 \\
(0.82-31.19)\end{array}$ \\
\hline
\end{tabular}

Table 7: Birth weight.

\begin{tabular}{|llll|}
\hline & $\begin{array}{l}\text { Cases } \\
(\mathrm{n}=70)\end{array}$ & $\begin{array}{l}\text { Controls } \\
(\mathrm{n}=70)\end{array}$ & $\begin{array}{l}\text { Level of } \\
\text { significance }\end{array}$ \\
\hline LBW & 10 & 4 & $\begin{array}{l}\mathrm{P}=0.011 \\
\mathrm{OR}=4.46 \\
(1.19-18.33)\end{array}$ \\
\hline VLBW & 37 & 0 & $\mathrm{P}=0.0001$ \\
\hline Nl weight & 23 & 66 & \\
\hline
\end{tabular}


Table 8: Sex of baby.

\begin{tabular}{|llll|}
\hline & $\begin{array}{l}\text { Cases } \\
(\mathrm{n}=70)\end{array}$ & $\begin{array}{l}\text { Controls } \\
(\mathrm{n}=70)\end{array}$ & $\begin{array}{l}\text { Level of } \\
\text { significance }\end{array}$ \\
\hline Males & 40 & 25 & $\begin{array}{l}\mathrm{P}=0.011 \\
\text { (Significant } \\
\text { for males) }\end{array}$ \\
\hline Female & 30 & 35 & \\
\hline
\end{tabular}

Although induced labour was associated with more neonatal jaundice but the difference was not statistically significant $[\mathrm{OR}=1.53$, CI (0.68-3.42)]. Regarding Oxytocin usage, there were no significant differences between the groups neither in the numbers given oxytocin nor in how it was used. The maximum dose ranges and duration of administration between the groups were the same.

Table 6 shows selected infant characteristics and occurrence of NNH. No statistically significant difference was found in those fetuses with meconium staining of amniotic fluid and those with clear liqour. Asphyxia was an important cause of neonatal jaundice. Apgar scores were estimated at 1' and 5'. Low Apgar scores were found to be significantly associated with $\mathrm{NNH}[\mathrm{p}=0.049$, $\mathrm{OR}=4.39$ : CI (0.82-31.19)].

As seen in Table 7, Mean birth weight was lower in the neonatal hyperbilirubinemia group $-2.50 \mathrm{~kg}$ compared to controls $-2.803 \mathrm{~kg}$. VLBW had a $\mathrm{p}=0.0001$, showing a strong association between birth weight and NNH.

Table 8 shows the relationship of sex of the baby with the incidence of neonatal hyperbilirubinemia. Male babies predominated jaundiced group (57\%).

Decreased frequency of breast feeding was seen to be associated with exaggeration of physiological jaundice.

$\mathrm{NNH}$ may be the only obvious symptom of hypothyroidism in neonatal period. $6 \%$ of babies with NNH had maternal hypothyroidism.

\section{DISCUSSION}

This study was undertaken to find out the contributions of each of the several associated variables. Jaundice of unexplained etiology is a serious clinical problem in this hospital, involving not only a hazard to infants but also taking much valuable time of laboratory and medical staff. Keren et al had done a comparison for predicting $\mathrm{NNH}$ in term and near term infants and he also showed that prematurity was an important risk factor for developing NNH. There were $21 \%$ of cases with $\mathrm{NNH}$ who were delivered prematurely and this association was statistically significant. The only clinical risk factor that could be added to the predischarge risk zone to improve overall predictive accuracy was gestational age. ${ }^{1}$
Circumstances in which cervical dilatation may have been performed earlier occurred, twice as common in the past obstetric histories of the jaundiced group mothers. These mothers delivered, in general earlier than the control group mothers and this was partly because of early inductions. In our study also, patients with previous history of abortions had a higher chance of developing Neonatal Hyperbilirubinemia though not statistically significant. $^{2}$

Our study demonstrated an OR of 5.6 for patients with GDM and those with hypertension, IUGR an ODD ratio of 1.3, which was statistically significant. The exact cause for this association is not known. May be a degree of fetal hypoxia associated with hypertension and IUGR may be a risk factor for developing neonatal jaundice.

David et al showed that infants of mothers whose labours were induced with oxytocin developed higher mean serum bilirubin levels than infants whose mothers had not received oxytocin at all. ${ }^{3}$ Ghosh et al did not find an increase in jaundice with oxytocin. ${ }^{4} \mathrm{We}$ also found no relationship between oxytocin administration, either for induction or acceleration and the development of significant jaundice.

Low birth weight, low Apgar scores at birth, evidence of fetal asphyxia was found to be strongly associated with development of early neonatal jaundice. Hyperbilirubinemia in preterm infants is more prevalent, more severe and its course more protracted than in term neonates as a result of exaggerated neonatal red cell, hepatic and gastrointestinal immaturity. ${ }^{5-8}$ The postnatal maturation of hepatic bilirubin uptake and conjugation may also be slower in preterm infants.

Najib et al in his study in Iran mentioned that causes of severe hyperbilirubinemia in the entire world are similar, but more investigations need to be done to find out the unknown causes. In their study, risk factors of severe hyperbilirubinemia was detected as 1) Male sex, 2) previous siblings with severe hyperbilirubinemia, 3) early discharge, 4) Normal vaginal delivery (it may be due to early discharging of neonates with normal delivery than cesarean section), 5) Breast feeding and 6) concept of using herbal medicine instead of referring to Doctor when neonate had Icter. ${ }^{9}$

According to Neil et al no single explanation for the jaundice epidemic was found. It appears that it may be due in part to a shift in the distribution of gestational ages, many more infants now being born before 40 weeks of gestation. This shift is partly due to more early inductions of labour as a result of a policy of active management of labour; it may also be due partly to earlier delivery because of previous cervical dilatation. The association between epidural anaesthesia and jaundice remains obscure. ${ }^{10,11}$ 
Bertini et al $^{12}$ demonstrated a statistically significant positive correlation between patients with a total serum bilirubin concentration $>12.9 \mathrm{mg} / \mathrm{dL}(221 \mu \mathrm{mol} / \mathrm{L})$ and supplementary feeding; oppositely, breastfed neonates did not present a higher frequency of significant hyperbilirubinemia in the first days of life. Their study confirms the important role of fasting in the pathogenesis of neonatal hyperbilirubinemia, although breastfeeding per se does not seem related to the increased frequency of neonatal jaundice. These infants, when starved and/or dehydrated, could probably be at high risk of bilirubin encephalopathy.

\section{CONCLUSION}

The incidence of Neonatal Hyperbilirubinemia is on the rise. That was what prompted us to undertake this study but as such no single explanation for the jaundice epidemic was found. It appears that it may be due in part to a shift in the distribution of gestational ages, many more infants now being born before 40 weeks of gestation. This shift is partly due to more early inductions of labour as a result of a policy of active management of labour. Presence of maternal complications like GDM, HTN and IUGR are found to be significant associations with occurrence of Neonatal Hyperbilirubinemia.

\section{ACKNOWLEDGEMENTS}

We would like to express our heartfelt gratitude to Department of paediatrics, Govt. Medical College Kozhikode, Kerala, India and Dr. Ajitha BK- Statistician Govt. Medical College Kozhikode, Kerala, India.

Funding: No funding sources Conflict of interest: None declared

Ethical approval: The study was approved by the Institutional Ethics Committee

\section{REFERENCES}

1. Keren R, Luan X. A Comparison of Alternative Risk-Assessment Strategies for Predicting Significant Neonatal Hyperbilirubinemia in Term and Near-Term Infants. Am Acad Pediatrics. 2008;121(1).

2. Wong YK, Wood BSB. Preliminary communications. British Medical Journal. 1971;4:403.

3. Davies DP. Neonatal Jaundice and Maternal Oxytocin Infusion. British Medical Journal. 1973;3:476.

4. Ghosh A, Hudson FP. Lancet. 1972;2:823-2.

5. Billing $\mathrm{BH}$, Cole $\mathrm{PG}$, Lathe GH. Increased plasma bilirubin in newborn infants in relation to birth weight. BMJ. 1954;2:1263-5.

6. Harris RC. Peak levels of serum bilirubin in normal premature infants. In: Sass-Kortsak A, ed. Kernicterus. Toronto, Canada: University of Toronto Press, 1961:10-12.

7. Watchko JF. The clinical sequelae of hyperbilirubinemia. In: Maisels MJ, Watchko JF, eds. Neonatal jaundice. Amsterdam: Harwood Academic Publishers, 2000:115-35.

8. Cashore WJ. Bilirubin and jaundice in the micropremie. Clin Perinatol. 2000;27:171-9.

9. Najib K, Saki F, Hemmati F, Inaloo S. Incidence, Risk Factors and Causes of Severe Neonatal Hyperbilirubinemia in the South of Iran (Fars Province). Iran Red Cres Med J. 2013;15(3):260-3.

10. May-Jen H, Ka-Em K. Risk Factors for Severe Hyperbilirubinemia in Neonates Pediatric Research. Iran Red Cres Med J. 2004;56:682-9.

11. Campbell N, David Harvey AP. Norman, Increased Frequency of Neonatal Jaundice in a Maternity Hospital. British Medical Journal. 1975;2:548-52.

12. Bertini G, Dani C. Is Breastfeeding Really Favoring Early Neonatal Jaundice? Pediatrics. 2001;107(3).

Cite this article as: Sumangala Devi D, Bindu V. Risk factors for neonatal hyperbilirubinemia: a case control study. Int J Reprod Contracept Obstet Gynecol 2017;6:198-202. 